\title{
Participatory Evaluation of Different Multipurpose Grass Species for Graded Soil Bund Stabilization in Gimbo District, South West Ethiopia
}

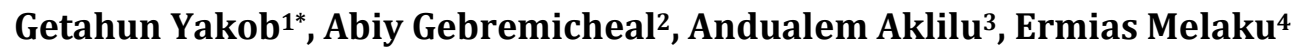 \\ ${ }^{1}$ Southern Agricultural Research Institute (SARI), Hawassa, Ethiopia \\ ${ }^{2}$ Bonga Agricultural Research Center, Bonga, Ethiopia \\ ${ }^{3}$ Ethiopian Civil Service University, Addis Ababa, Ethiopia \\ ${ }^{4}$ Jimma University College of Agriculture and Veterinary Medicine, Jimma, Ethiopia \\ Email: ${ }^{*}$ getahunyakob@gmail.com
}

Received 30 May 2015; accepted 19 June 2015; published 23 June 2015

Copyright (C) 2015 by authors and OALib.

This work is licensed under the Creative Commons Attribution International License (CC BY). http://creativecommons.org/licenses/by/4.0/

(c) (i) Open Access

\section{Abstract}

Soil erosion is one of the biggest threats to agricultural productivity in South West Ethiopia. Steep slopes, high rainfall and fragile ecosystem characterize these production systems. To reverse this trend, integration of physical and biological soil and water conservation measures is very important. This study was conducted to evaluate different multi-purpose grass species as soil bund stabilizers. Graded soil bunds were constructed on selected eight farmers' farmland and five grass stabilizers were grown on the embankment of the bund. Five soil bund stabilizers are i) vetiver grass, ii) elephant grass, iii) desho grass, iv) rodes grass, and v) guinea grass. Data on the survival, biomass, and frequency of harvest of those stabilizers on the soil bund were collected. Soil samples were also taken before and after the establishment of experiment. Furthermore, performance criteria were established through group discussions with farmers, and stabilizer (grass) performance was later evaluated according to these criteria. The criteria were weighted using pair-wise ranking and scored with a scale of 1 (not good) to 5 (best) based on each criterion. Desho grass was found to survive and establish on the embankment of soil bund earlier (10 - 25 days) than the others and followed by elephant and vetiver grass. Furthermore, desho grass was observed to have higher green biomass and frequency of harvest compared to elephant and vetiver grasses. Results of soil chemical properties (Soil N, soil P, Soil K, \% OC, pH and CEC) revealed no significant differences in amount of total $N$, and available $P$ and $K$ between the soils of "before" and "after" the establishment of integrated soil bund. Based on the overall weighted scores obtained using pairwise ranking approach, desho grass ( $P$. pedicelluatum) was found to be the overall most desirable stabilizers and followed by elephant (Pennisetum purpureum) and vetiver (Vetiverial zizanioides)

"Corresponding author.

How to cite this paper: Yakob, G., Gebremicheal, A., Aklilu, A. and Melaku, E. (2015) Participatory Evaluation of Different Multipurpose Grass Species for Graded Soil Bund Stabilization in Gimbo District, South West Ethiopia. Open Access Library Journal, 2: e1627. http://dx.doi.org/10.4236/oalib.1101627 


\title{
grasses in the study area. Therefore, there is a need to develop SWC practices with stabilizers such
} as desho and elephant grasses.

\section{Keywords}

\author{
Soil Bund, Stabilizers, Pair-Wise Ranking, Biomass, Frequency of Harvest
}

\author{
Subject Area: Agricultural Science
}

\section{Introduction}

More than $80 \%$ of Ethiopian population is engaged in agricultural activities [1], which is dependent on land resource. However, the agricultural system is under continuous threat from land degradation resulting from soil erosion and soil fertility depletion. This phenomenon has caused several negative impacts on land [2] [3], and seriously limits food security and sustainable agricultural production in the country [4]-[10].

Although estimates of the extent and rate of soil erosion and associated nutrient losses lack consistency, several studies indicate the severity of the problems in different parts of the country. The highest rate of soil loss occurs from cultivated lands, ranging from $50 \mathrm{t} \cdot \mathrm{ha}^{-1} \cdot \mathrm{yr}^{-1}$ [11] to $179 \mathrm{t} \cdot \mathrm{ha}^{-1} \cdot \mathrm{yr}^{-1}$ [12]. In contrast, according to Hurni [13], the average soil formation rates for wet weina dega (1500 - 2300 masl and $>1400 \mathrm{~mm}$ rainfall) and moist weina dega (1500 - 2300 masl and $900-1400 \mathrm{~mm}$ rainfall) is 16 and $12 \mathrm{t} /$ hay respectively.

Cognizant of these problems, efforts to regulate the impacts of land degradation on soil productivity have been undertaken in various parts of the country. Major types of conservation methods introduced were structural type and of these the most common were the fanya juu and soil bunds [14]. Accordingly, some successes of soil bunds have been recorded for resource conservation in the country. For instance, soil bunds reduced soil loss by 39 percent in Tigray [15] and by 50 percent in Anjeni [16]. Besides, soil bunds promote rainwater infiltration [17]. However, the adoption of SWC practices is very low [11] [18]. This could be due to farmers' concern for wastage of productive land which could be used for crops, and the lack of integration of physical conservation structures with biological measures.

Therefore, for better adoption of physical soil and water conservation technologies, integrating with biological SWC (grasses) is very important. This is because grasses can provide multipurpose functions to farmers. That is, they can be used as animal feed, stabilize physical measures to reduce maintenance cost, and reduce soil erosion. Information on management of integrated physical and biological conservation measures is very crucial for reduction of soil erosion from farmlands, hence contributing to sustainable soil conservation. So far, no studies have been conducted on the performance of biological stabilizer on SWC practices that explicitly integrates farmers' needs and environmental objectives in South West Ethiopia.

The effectiveness of soil bund stabilizers is site specific and highly variable. Evaluating the performance of different vegetative materials on the embankment of soil bund in the study area is important to inform farmers on the effectiveness of SWC technology and persuade them to integrate physical SWC practices with biological conservation measures. Therefore, this study was conducted in Gimbo district on farmers' field to evaluate different multi-purpose grass species as soil bund stabilizers.

\section{Materials and Methods}

Description of the study area: The study was conducted in Gimbo district at Shomba Kichib kebele, South West Ethiopia. The area lies within $07^{\circ} 00^{\prime} \mathrm{N}-7^{\circ} 25^{\prime} \mathrm{N}$ Latitude and $35^{\circ} 55^{\prime} \mathrm{E}-36^{\circ} 37^{\prime} \mathrm{E}$ Longitude. It has an altitude range of $1001-2500$ masl. The area is characterized by a long rainy season that extends from March to October. The average rainfall amount of the area ranges from $1401-2000 \mathrm{~mm}$. The mean maximum and minimum temperatures are $15.1^{\circ} \mathrm{C}-22.5^{\circ} \mathrm{C}$, respectively. The soils of the area are deep, clay red soils with an agric B-horizon dystric nitosols. The soils have good agricultural potentialities, good physical properties and uniform profile. They are porous, clay-to-clay loam in texture and have low base saturation with less than $5.5 \mathrm{pH}$ values and well drained [19]. The farming system is a typical mixed crop-livestock system on a subsistence scale (Figure 1).

Site selection, farmer selection and discussion: Team embracing farmers, DAs, experts of the BOA and re- 


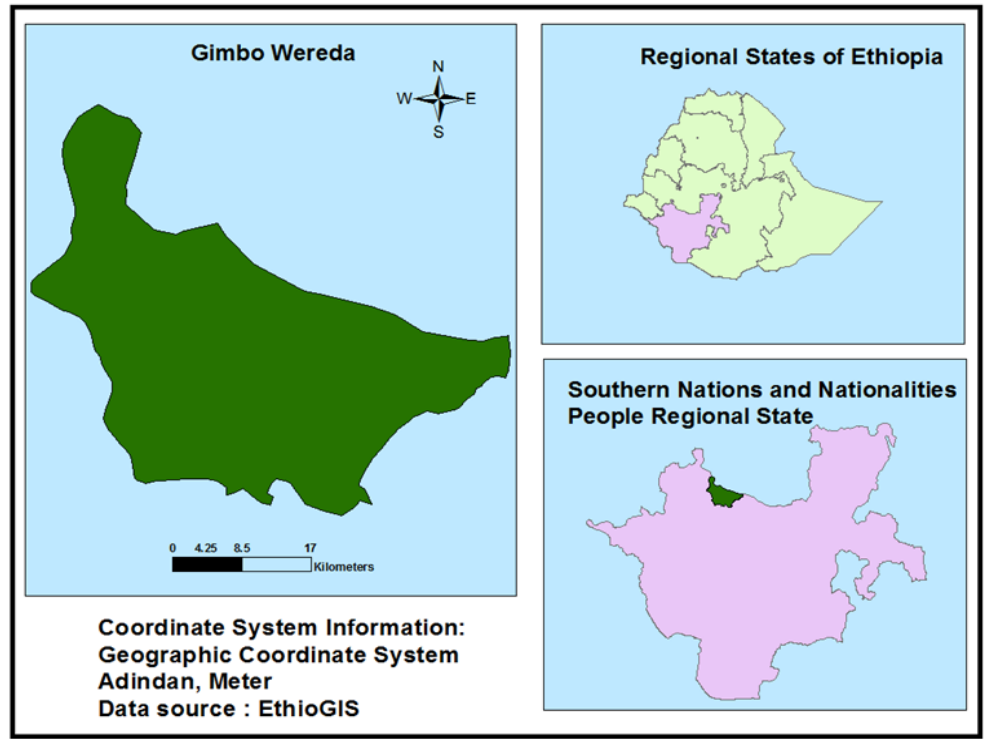

Figure 1. Map of the study area.

search staff was formed. Before the implementation of the project, priority activity was given for creating awareness to farmers and stakeholders. The team worked on awareness creation through individual and group discussions with farmers as to the present and future deleterious effects of land degradation at watershed approach. During the discussion, the past and present threat of land degradation broadly in the country and specifically in the area was explicitly explained. The mitigation measures and their sustainability were also raised in detail. Farmers explained the impact (negative as well as positive) of the past soil and water conservation activities. Moreover the multipurpose bund stabilizer grass species especially those with benefit as soil bund stabilizer and forages were discussed thoroughly. They raised the main problem of animal free grazing during off season (winter time) when crops are harvested from the land during which free grazing by animals takes place which could affect the trial. Since the experiment was participatory, the area specific by laws were prepared to reduce the risk of thus problem. Farmers express their attitude as follows. 'We understood and recognized very well practically how soil erosion affects our farm lands. Therefore, we are happy to host the trial'.

Soil bund design and construction: Graded soil bund is suitable mostly in high rainfall and humid areas of wetter agro ecologies and especially where the soil is poorly drained [20]. Since the area receives high rainfall, graded soil bund with $1 \%$ gradient was constructed. The soil bund was constructed during dry season and at a period not interfering with land preparation. During construction of the bund, the land owners participated with their families in group. After survey line was prepared, the farmers use their own oxen to prepare ditch so that it became simple to construct. Soil bunds in the watershed were constructed based on the soil and water conservation guideline of the Ministry of Agriculture [20]. The horizontal distance between two successive soil bunds was determined based on the vertical interval between bunds (usually $1 \mathrm{~m}$ for Ethiopia) and the slope angle [21]. The base width and top width of the bund (embankment) were from $1 \mathrm{~m}$ to $1.2 \mathrm{~m}$ and $0.30 \mathrm{~m}$ to $0.50 \mathrm{~m}$ respectively. Besides, the height of the bund was $0.60 \mathrm{~m}$ after compaction. However, in addition to technical standard, farmers' suggestion and modification based on their interest was incorporated while constructing the bund.

Trial design: The trial started in the 2008/2009 growing season with eight volunteer farmers with adjacent farm fields. Five grass stablizers (treatments) namely, Vetiver (Vetiverial zizanioides), Elephant (Pennisetum purpureum), Desho (Pennisetum pedicelluatum), Guinea (Panicum coloratum L.) and Rodes (Chloris gayana) were put on constructed soil bund found on each farmer's field (Slope: $25 \%-30 \%$ ). Each stabilizer was planted/ seeded on three strip of soil bund with recommended planting pattern (Table 1). Eight trial farmers were considered as a replication. Seeds (Guinea and Rodes) and cuttings (Vetiver, Elephant and Desho) of stabilizers were obtained from SOS sahel, Debrezeit and Holleta Agricultural research centers

Data collection and analysis: Data on biological performance of stabilizers, farmers' perception and soil properties were collected using standard procedures. Data on farmers' perception towards the stabilizers were collected using two focus group discussions (FGDs) $(n=8)$. The small numbers of FGDs $(n=2)$ is due to li- 
Table 1. Planting pattern and seed rates of stabilizers.

\begin{tabular}{cc}
\hline Grass stabilizer & Planting pattern \\
\hline Vetiverial zizanioides & $40 \mathrm{~cm}$ \\
Pennisetum purpureum & $40 \mathrm{~cm}$ \\
Pennisetum pedicelluatum & $30 \mathrm{~cm}$ \\
Panicum coloratum L & Broadcasting \\
Chloris gayana & Broadcasting \\
\hline
\end{tabular}

mited numbers of farmers who had implemented the integrated physical and biological soil and water conservation practices. As a result, almost all farmers participated in the FGDs. Usually, farmers aim at multiple objectives with soil bund stabilizers. Farmers were asked to list criteria they would like to consider in the preference of stabilizers. Eleven criteria were defined after focus group discussions. These criteria included rate of survival, low labour requirement, reduce soil loss, stabilizing the bund, fast growing, use for forage, use for thatching house, drought resistance, resistance for free grazing, easy for maintenance and retained soil moisture. Farmers were asked to prioritize different SWC practices by giving scores based on each criterion from the scale of 1 for not good to 5 for the best. The scores were averaged. The SWC practices include: soil bund alone (SB), soil bund with Desho grass (P. pedicelluatum) $(S B+D g)$, soil bund with Elephant grass (Pnnisetum purpureum) (SB $+E g$ ), and soil bund with Vetiver $(V$. zizanioides $)(S B+V s)$. In addition pair-wise ranking technique was employed. Typically, the criteria were weighted using pair-wise ranking by decision makers (farmers) to reflect their relative importance. Data were also collected on the performance of stabilizers such as amount, height, and frequency of harvesting. A composite soil sample was collected from $0-20 \mathrm{~cm}$ to evaluate different soil chemical properties (Total N, available P, K, OM, PH, and CEC) before establishment and after accomplishment of the trial. All soil parameters were analyzed using standard laboratory procedures. A two tailed t-test at $5 \%$ level of significance was used to test differences in soil parameters between before and after the experiment.

\section{Results and Discussion}

\subsection{Biological Performance of Stabilizers}

Survival of grasses on the soil bund: A comparison of the survival of different stabilizers on the soil bund is shown in Table 2. Accordingly, performances of individual grass stabilizers were variable. Desho grass was found to survive earlier (10 - 15 days) compared to the others and followed by Elephant (15 - 25 days) and Vetiver (25 30 days). Desho grass was also found to establish and cover the embankment of the soil bund earlier than elephant and vetiver (Figures 2-4)). This is could be due to fast growing nature of the grass [22]. However, height of elephant grass at maturity was found to be higher compared to the others. Unlike Desho and Elephant grass, Ginuea grass took months to germinate and grow (Figure 5). Poor performance of Guinea grasses on soil bund could suggest that it is difficult to establish seeded grass stabilizers. Zenebe et al [23] reported that suitable stabilizers, grasses or shrubs, are needed to compensate the yield losses caused by the construction of soil bunds and re-enforce the structures.

Stabilizers at Harvest: The first green biomass yield harvest of both desho and elephant grasses was carried out after three months of planting while the second harvest was done after 2.5 months. Whereas, the first vetiver yield was harvested after 5 months of planting. Green biomass yield of stabilizers was variable. As shown in Table 3, the first harvested elephant, desho and vetiver grasses yield (green biomass) was $18.6 \mathrm{~kg} / \mathrm{m}^{2}, 9.53$ $\mathrm{kg} / \mathrm{m}^{2}, 7.6 \mathrm{~kg} / \mathrm{m}^{2}$, respectively. The second green biomass was harvested after 2.5 months. Desho and elephant grasses were observed to have 4 - 5 harvesting frequency per a single rainy season which lasts for five consecutive months.

\subsection{Soil Properties}

Laboratory analysis of the soils before establishment of integrated conservation measure showed that the soils are loamy or silty loam or clay loam in texture. The soils were also found to be moderately acidic ranging from 

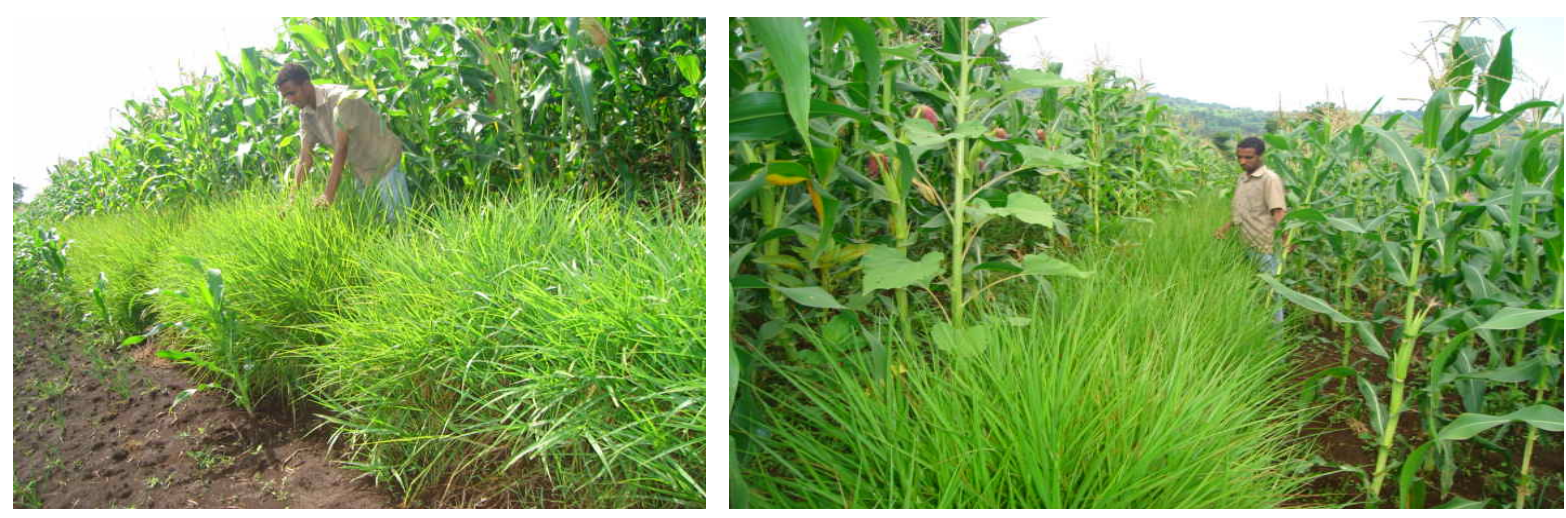

Figure 2. High performance of Desho grass on the bund.
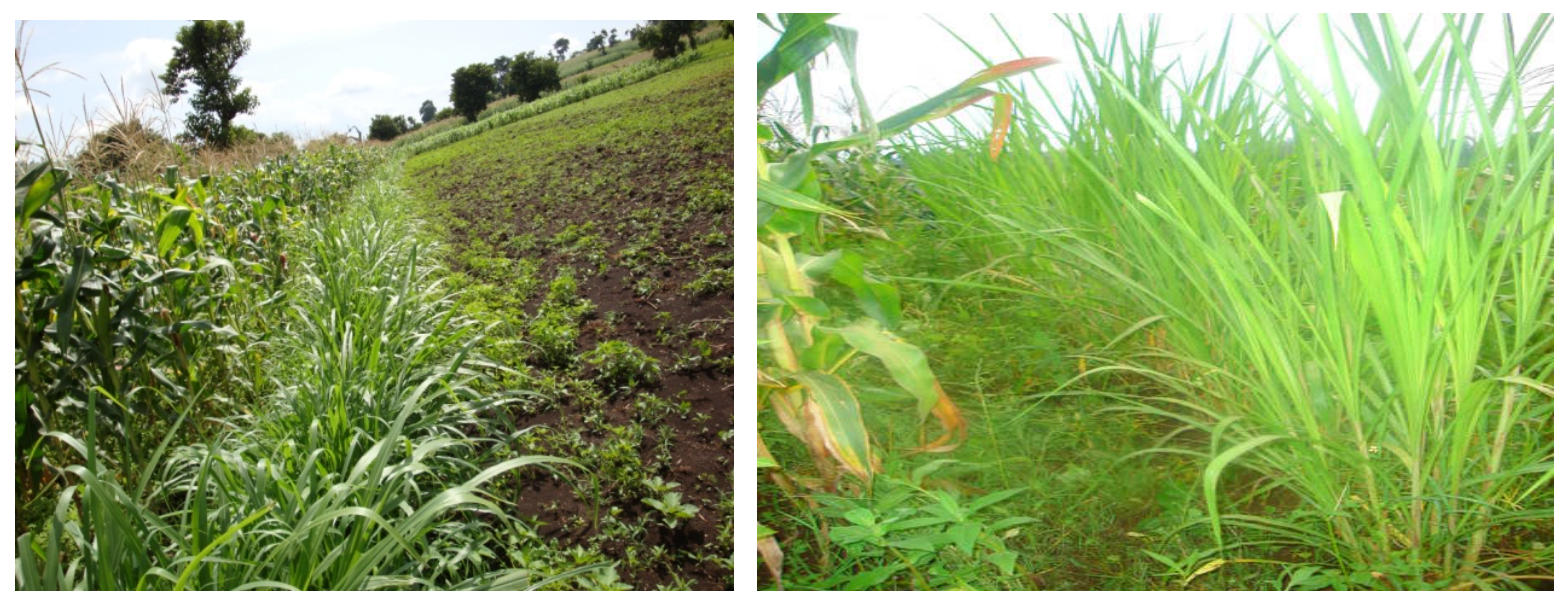

Figure 3. The soil bund stabilized with elephant grass.

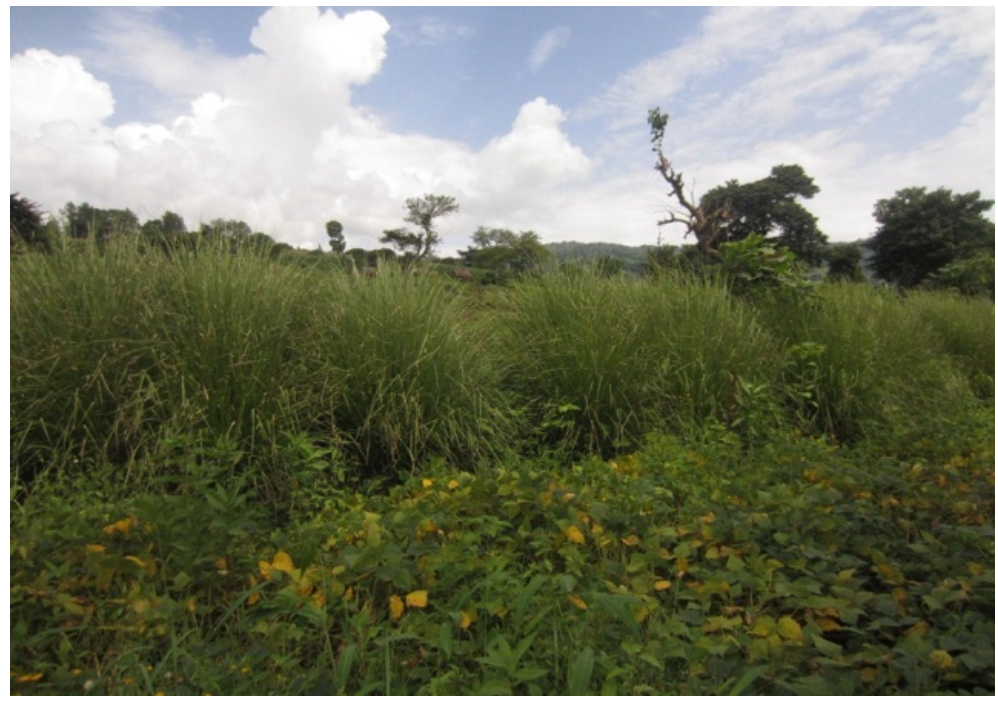

Figure 4. Vetiver grass.

$\mathrm{pH}$ levels of 6 to 6.8. The mean soil organic $\mathrm{C}$ and nutrient contents, $\mathrm{pH}, \mathrm{CEC}$ and level of significant variations before and after experiment are given in Table 4. The results of soil analysis at $0-15 \mathrm{~cm}$ revealed that no significant differences in amount of total N, available $\mathrm{P}$ and $\mathrm{K}$ between the soils of 'before' and 'after' the establishment of integrated soil bund. The lack of significant difference in the aforementioned parameters attributed 


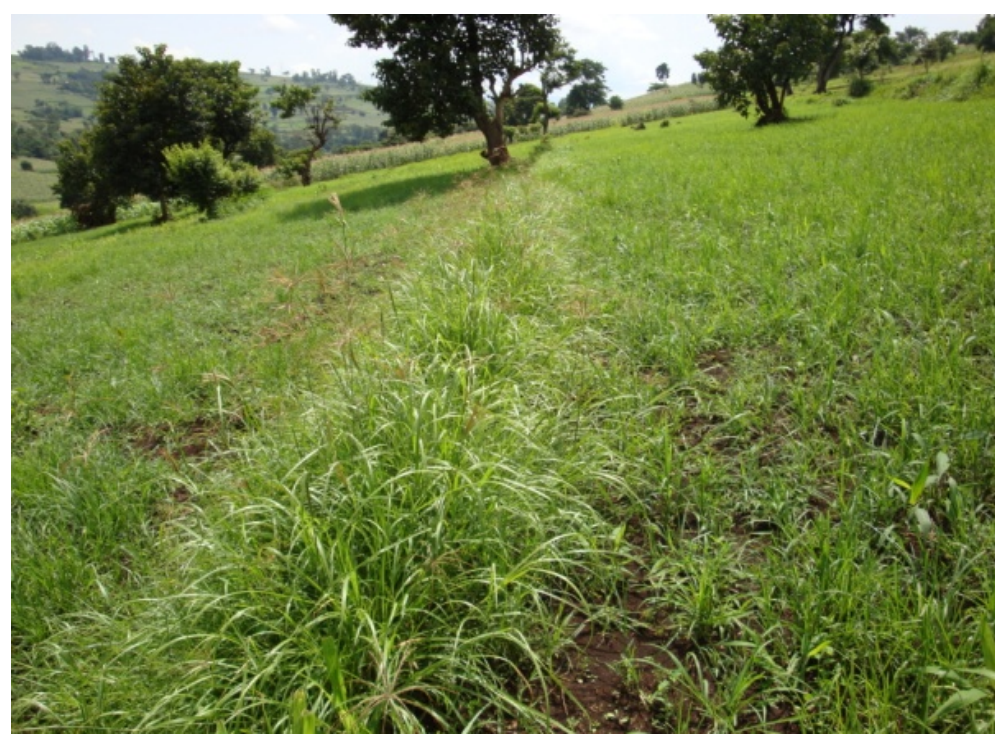

Figure 5. Guinea grass.

Table 2. Average survival time of stabilizers in the study area with given management.

\begin{tabular}{ccccc}
\hline Stabilizers & Local name & SD & MH $(\mathbf{m})$ & AGWB $(\mathbf{k g} / \mathbf{s q m})$ \\
\hline P. pedicelluatum & Desho & $10-15$ & 1.4 & 10.8 \\
P. purpureum & Elephant & $15-25$ & 2.7 & 26 \\
V. zizanioides & Vetiver & $25-30$ & 1.2 & 11.5 \\
P. coloratum & Guinea & $9 \mathrm{M}^{*}$ & 1 & 0.28 \\
C. gayana & Rodes & $* *$ & $* *$ & $*$ \\
\hline
\end{tabular}

$\mathrm{SD}=$ Survival date after planting; $\mathrm{MH}=$ Maximum height; $\mathrm{AGWB}=$ Average green biomass weight. ${ }^{* *}$ Failed to survive for a given time as a result of moisture stress for germination; "Month.

Table 3. The green biomass yield and average height taken at the first and second harvest.

\begin{tabular}{ccccc}
\hline \multirow{2}{*}{ Type of grasses } & \multicolumn{2}{c}{ Weight $(\mathbf{k g} / \mathbf{m . s q})$} & \multicolumn{2}{c}{ Average height $(\mathbf{m})$} \\
\cline { 2 - 5 } & 1st harvest & 2nd harvest & 1st harvest & 2nd harvest \\
\hline P. pedicelluatum & 9.53 & 18.52 & 1.22 & 1.2 \\
P. purpureum & 18.6 & 16.3 & 1.87 & 2.5 \\
V. zizanioides & 7.6 & 11.5 & 0.9 & 1.1 \\
P. coloratum & 0.28 & $* *$ & 0.84 & $* *$ \\
C. gayana & $* *$ & $* *$ & $* *$ & $*$ \\
\hline
\end{tabular}

***ailed to survive.

Table 4. The results from the chemical analysis on the composite soil samples taken before and after the experiment from all farmlands under study.

\begin{tabular}{ccccccc}
\hline & \multicolumn{5}{c}{ Soil parameters } \\
\cline { 2 - 7 } & Total N (\%) & Available P (ppm) & $\begin{array}{c}\text { Available K } \\
(\text { Meq/100 gm })\end{array}$ & SOC (\%) & CEC (Meq/100 gm) & pH ( $\left.\mathrm{H}_{2} \mathrm{O}\right)$ \\
\hline Before experiment & 0.233 & 5.572 & 0.322 & 3.084 & 20.18 & 6.02 \\
After experiment & 0.215 & 5.639 & 0.220 & 1.495 & 15.86 & 5.85 \\
\hline
\end{tabular}

N: Nitrogen; P: Phosphorous; K: Potassium; OC: Organic carbon; CEC: Cation exchange capacity. 
to the fact that physical soil conservation measures did not lead to increases in nutrient content of the soil. Ray [24] and Thomas [25] observed similar results that physical measures did not bring about increases in nutrient content. This does not suggest that physical conservation measures should not be undertaken in the face of growing soil erosion problems. The results of the study show that efforts should be geared forwards implementing physical soil conservation measures, alongside with fertility improving methods. Soil conservation is fundamentally a matter of determining a correct form of land use and management [26]. Soil loss can be reduced by appropriate crop management, which includes cover cropping, multiple cropping, and high density planting [27]. CEC and SOC concentrations were significantly higher before establishment of the project compared to the end of the project period. This could be attributed to continuous cropping and absence of organic matter addition. Repetitive tillage with complete removal of residues leads to deterioration of soil fertility and productivity decline in the long-run.

\subsection{Farmer's Perception towards Soil and Water Conservation}

Results for the farmers' scores of the SWC practices are presented in Table 5. The values reflected the perceived degree of importance of each SWC practices based on their criteria. Generally, farmers gave scores based on the multipurpose nature of the stabilizers. Accordingly, the average rank shows that farmers gave the highest total score for SB + Dg followed by SB + Eg and SB + Vg. In all criteria, farmers gave the lowest total score for soil bund alone (SB). However study by Zenebe et al. [23], in central highlands of Ethiopia, revealed that the highest total scores for SB + Eg followed by SB + Sg and SB + Vg. Similarly a study in the central highlands of Ethiopia shows that SB alone reduced crop yield by about 7 percent, which is entirely explained by the reduction of the cultivable area by 8.6 percent [28]. In other study in Southern Ethiopia indicated that one of the constraints of soil and water conservation is lack of integrated bio-physical measures [29].

The pair wise result below also indicated that Desho grass is ranked first followed by Elephant and Vetiver (Table 6). The grass was found extremely superior to the other introduced grasses species in terms of different farmers' criteria. The discussion with farmers showed that Desho is highly valuable in addition to soil bund stabilization. They said the grass is fast growing, easy to establish and maintain, needs lesser management and has higher palatability and harvesting frequency than the others (Figure 6 and Figure 7). Besides, the grass is not

Table 5. Farmers' average scores ${ }^{1}$ of different SWC practices $^{2}$ based on evaluation criteria.

\begin{tabular}{|c|c|c|c|c|}
\hline \multirow{2}{*}{ Criteria of comparison } & \multicolumn{4}{|c|}{ Preference ranking } \\
\hline & SB & SB + Dg & $\mathbf{S B}+\mathbf{E g}$ & $\mathbf{S B}+\mathbf{V g}$ \\
\hline Rate of Survival & - & 5 & 4 & 2 \\
\hline Easy for management & 2 & 4 & 3 & 3 \\
\hline Reduce soil loss & 3 & 5 & 5 & 4 \\
\hline Stabilizing the bund & 1 & 5 & 4 & 3 \\
\hline Fast growing & - & 5 & 4 & 2 \\
\hline Use for forage & - & 5 & 4 & 1 \\
\hline Use for thatching house & - & 1 & 1 & 5 \\
\hline Drought resistance & - & 3 & 3 & 5 \\
\hline Resistance for free grazing & - & 4 & 4 & 5 \\
\hline Retain soil moisture & 2 & 3 & 3 & 3 \\
\hline Easy for maintenance & 1 & 5 & 4 & 3 \\
\hline Average & 2 & 4 & 3.5 & 3.2 \\
\hline
\end{tabular}

Scores: 5 = Best; 4 = Very good; $3=$ Good; $2=$ Average; $1=$ Not good. $\mathrm{SB}=$ Soil bund alone; $\mathrm{SB}+\mathrm{Dg}=$ Soil bund with desho grass; $\mathrm{SB}+\mathrm{Eg}=\mathrm{Soil}$ bund with elephant grass; $\mathrm{SB}+\mathrm{Vg}=$ Soil bund with vetiver grass; $\mathrm{SB}+\mathrm{Rg}=$ Soil bund with rhodes grass; $\mathrm{SB}+\mathrm{Gg}=$ soil bund with Guinea grass. 

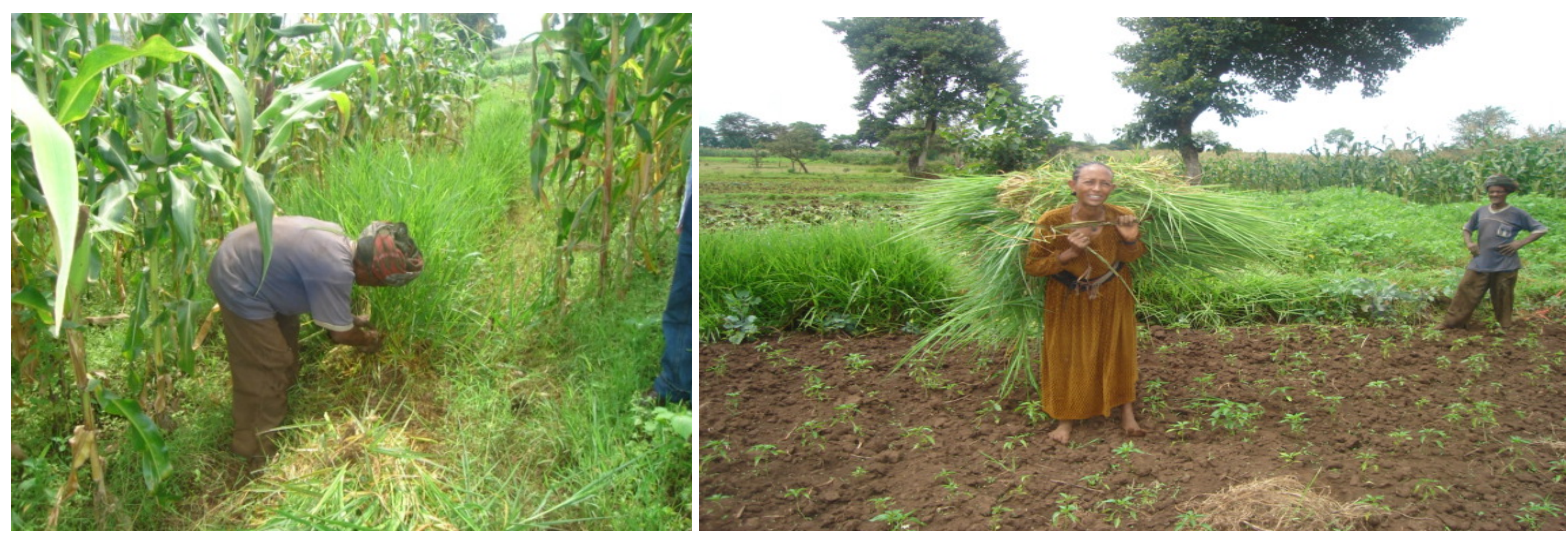

Figure 6. Desho grass harvested and transported as a cut-and carry system after bund stablization.
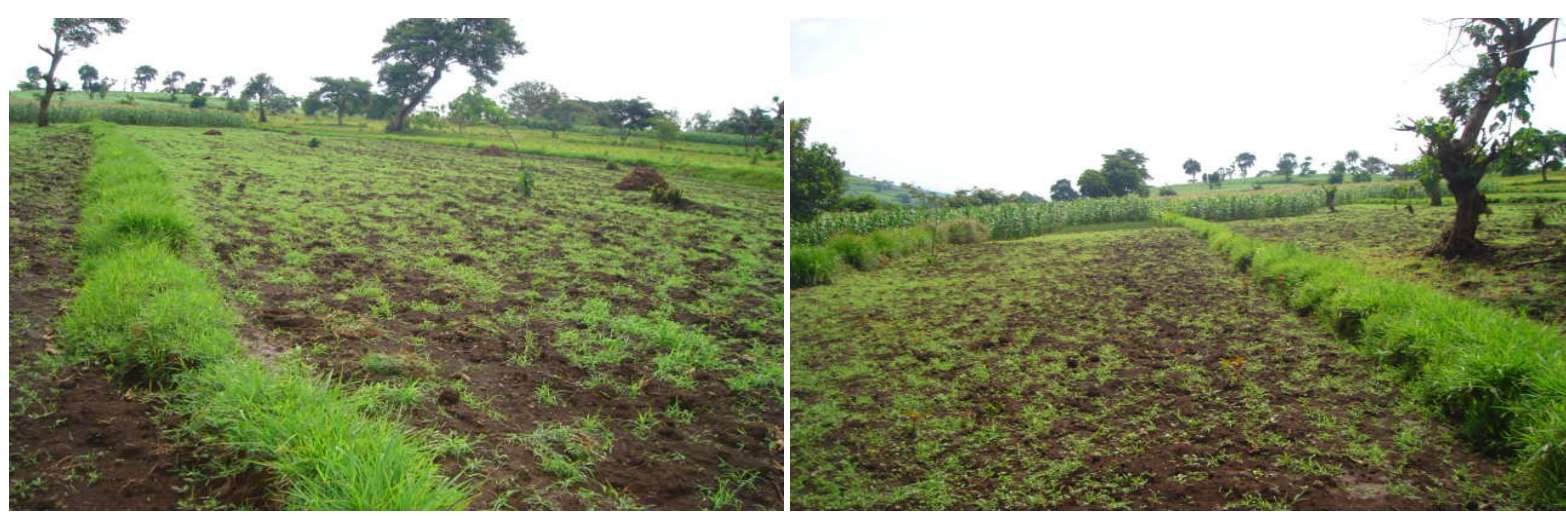

Figure 7. Desho regenerated after harvesting.

Table 6. Pair wise ranking of different SWC practices.

\begin{tabular}{ccccccc}
\hline & Bund & Desho & Elephant & Vetiver & Score & Rank \\
\hline Bund & & Desho & Elephant & Vetiver & 0 & 4 \\
Desho & Desho & & Desho & Desho & 3 & 1 \\
Elephant & Elehpant & Desho & & Elephant & 2 & 2 \\
Vetiver & Vetiver & Desho & Elephant & & 1 & 3 \\
\hline
\end{tabular}

invasive and can be managed easily. Dinku and Nedessa [30] reported that in addition to other benefits, desho grass has superior value in promoting livestock productivity and improving the livelihood of the beneficiaries. This implies that improving the productivity of conservation structures using multi-purpose grasses and shrubs can provide opportunities for enhancing the adoption of the technologies.

According to farmers, palatability of elephant grass decreases as its maturity increase. To stabilize the bund by elephant grass, approximately three months are enough. Mostly, it needs good management like weeding for the first one month, so that it grows fast dominating other weeds and stabilizing the bund. Prominence should be given to weeding time through weeding within 30 - 45 days to get vigor and sustainably efficient stabilizers. Vetiver grass is used by farmers for the purpose of thatching the house, thatching traditional bee hives, soil protection and mulching. But they raised its impact on taking the land by expanding widely both sides. The problem seems to be due to absence of timely management by reducing the newly developing tillers from upper and lower sides. All types of grasses are highly affected by shade plants like sorghum, maize and other long plants. So till it stabilize the bund, short plants like millet, teff and e.t.c should be used for any bund stabilizers.

Reluctance of farmers on the maintenance of the soil bunds and carrying out weeding were the major chal- 
lenges during conducting the experiments. Awareness creation is crucial on the importance of integrated biological and physical conservation measures. Furthermore, free grazing system (including open access during dry period) exercised in the study area poses serious limitations to grow these grasses. Therefore, a new land use policy that restricts free grazing is required at different administrative levels in Ethiopia.

\section{Conclusion}

The performance of stabilizers on soil bund has indicated that $P$. pedicelluatum, P. purpureum and Vetiverial zizanioides grasses are suitable for bund stabilization. They are also characterized by multiple benefits. Farmers' evaluation of stabilizers showed a higher interest in desho grass than the others for stabilization and other benefits. Physical soil conservation measures alone could not lead to improve the fertility and nutrient content of the soil. There is a need to integrate with vegetative and soil fertility improvement practices.

\section{Acknowledgements}

The authors really acknowledge Southern Agricultural Research Institute and Bonga Agricultural Research Centre for financing the study and facilitating the process.

\section{References}

[1] Central Statistical Authority (CSA) (2008) Statistical Abstract of Ethiopia. Central Statistical Authority, Addis Ababa.

[2] EPA (2003) State of Environment Report for Ethiopia. Addis Ababa, Ethiopia.

[3] CFSCDD/MoA (1986) Guidelines for Development Agents on Soil Conservation in Ethiopia. Switzerland.

[4] Shiferaw, B. and Holden, S. (2000) Policy Instruments for Sustainable Land Management: The Case of Highland Smallholders in Ethiopia. Agricultural Economics, 22, 217-232. http://dx.doi.org/10.1111/j.1574-0862.2000.tb00071.x

[5] Taddese, G. (2001) Land Degradation: A Challenge to Ethiopia. Environmental Management, 27, 815-824. http://dx.doi.org/10.1007/s002670010190

[6] Bewket, W. and Sterk, G. (2002) Farmers' Participation in Soil and Water Conservation Activities in the Chemoga Watershed, Blue Nile Basin, Ethiopia. Land Degradation \& Development, 13, 189-200. http://dx.doi.org/10.1002/ldr.492

[7] Bekele, W. and Drake, L. (2003) Soil and Water Conservation Decision Behavior of Subsistence Farmers in the Eastern Highlands of Ethiopia: A Case Study of the Hunde-Lafto Area. Ecological Economics, 46, 437-451. http://dx.doi.org/10.1016/S0921-8009(03)00166-6

[8] Gebremedhin, B. and Swinton, S.M. (2003) Investment in Soil Conservation in Northern Ethiopia: The Role of Land Tenure Security and Public Programs. Agricultural Economics, 29, 69-84. http://dx.doi.org/10.1111/j.1574-0862.2003.tb00148.x

[9] Wagayehu, B. and Lars, D. (2003) Soil and Water Conservation Decision of Subsistence Farmers in the Eastern Highlands of Ethiopia: A Case Study of the Hunde-Lafto.

[10] Woldeamlak, B. (2003) Land Degradation and Farmers' Acceptance and Adoption of Conservation Technologies in the Digil Watershed, Northwestern 99 Highlands Ethiopia. Social Science Research Report Series, No. 29. OSSERA, Addis Ababa.

[11] Adimassu, Z., Mekonnen, K., Yirga, C. and Kessler, A. (2014) Effect of Soil Bunds on Runoff, Soil and Nutrient Losses, and Crop Yield in the Central Highlands of Ethiopia. Land Degradation \& Development, 25, 554-564.

[12] Shiferaw, B. and Holden, S.T. (1999) Soil Erosion and Smallholders' Conservation Decisions in the Highlands of Ethiopia. World Development, 27, 739-752. http://dx.doi.org/10.1016/S0305-750X(98)00159-4

[13] Hurni, H. (1983) Soil Formation Rate in Ethiopia. Working Paper 2, Food and Agriculture Organization of the United Nations (FAO)/Ministry of Agriculture (MOA) Joint Project, Ethiopian Highlands Reclamation Study, Addis Ababa.

[14] Belay, T. (1992) Farmers' Perception of Erosion Hazards and Attitudes towards Soil Conservation in Gunono, Wolayita, Southern Ethiopia. Ethiopian Journal of Development Research, 14, 31-58.

[15] Gebreegziabher, T., Nyssen, J., Govaerts, B., Getnet, F., Behailu, M., Haile, M. and Deckers, J. (2008) Contour Furrows for in Situ Soil and Water Conservation, Tigray, Northern Ethiopia. Soil \& Tillage Research, 103, 257-264. http://dx.doi.org/10.1016/j.still.2008.05.021

[16] Herweg, K. and Ludi, E. (1999) The Performance of Selected Soil and Water Conservation Measures-Case Studies from Ethiopia and Eritrea. Catena, 36, 99-114. http://dx.doi.org/10.1016/S0341-8162(99)00004-1 
[17] Critchley, W.R.S., Reij, C. and Willcocks, T.J. (1994) Indigenous Soil and Water Conservation: A Review of the State of Knowledge and Prospects for Building on Traditions. Land Degradation \& Rehabilitation, 5, 293-314. http://dx.doi.org/10.1002/ldr.3400050406

[18] German, L., Mansoor, H., Alemu, G., Mazengia, W., Amede, T. and Stroud, A. (2007) Participatory Integrated Watershed Management: Evolution of Concepts and Methods in an Eco-Regional Program of the Eastern African Highlands. Agricultural Systems, 94, 189-204. http://dx.doi.org/10.1016/j.agsy.2006.08.008

[19] CBFED (2004) Coordination Bureau of Finance and Economic Development. Regional Atlas. Southern Nations, Nationalities and People's Regional Sate Bureau of Statistics and Population. E.M Press, Awassa.

[20] Ministry of Agriculture and Rural Development of Ethiopia (2005) Community Based Participatory Watershed Development: A Guideline e Part 1. MoARD, Addis Ababa.

[21] Ludi, E. (2004) Economic Analysis of Soil Conservation: Case Studies from the Highlands of Amhara Region, Ethiopia. Ph.D. Thesis, Institute of Geography, University of Bern, Bern.

[22] Liniger, H. and Critchley, W. (2007) Improved Grazing Land Management in Ethiopia. In: Liniger, H. and Critchley, W., Eds., Where the Land Is Greener: Case Studies and Analysis of Soil and Water Conservation Initiatives Worldwide, CTA, Wageningen.

[23] Adimassu, Z., Gorfu, B., Nigussie, D., Mowo, J. and Hilemichael, K. (2013) Farmers' Preference for Soil and Water Conservation Practices in Central Highlands of Ethiopia. African Crop Science Journal, 21, 781-790.

[24] Ray, H.H. (2007) The Effects of Physical Techniques on Soil Conservation in Mubi and Environs Adamawata State, Nigeria. Sustainable Development in Agriculture and Environment, 3, 112-121.

[25] Thomas, D.B. (1993) Choosing Conservation Measures for Copland in Small Holdings in Kenya. In: Hudson, N. and Cheatle, R.J., Eds., Involving with Farmers for Better Land Husbandry, SRP Ltd., Exeter.

[26] Sanders, D. (2004) Soil Conservation: Land Use, Land Cover and Soil Sciences. World Association of Soil and Water Conservation, Bristol.

[27] Junge, B., Abaidoo, R., Chikoye, D. and Stahr, K. (2008) Soil Conservation in Nigeria: Past and Present On-Station and On-Farm Initiatives. Soil and Water Conservation Society, Ankeny.

[28] Adimassu, Z., Kessler, A. and Hengsdijk, H. (2012) Exploring Determinants of Farmers' Investments in Land Management in the Central Rift Valley of Ethiopia. Applied Geography, 35, 191-198. http://dx.doi.org/10.1016/j.apgeog.2012.07.004

[29] Tsegaye, G. and G/Michael, A. (2014) Review on Overall Status of Soil and Water Conservation System and Its Constraints in Different Agro Ecology of Southern Ethiopia. Journal of Natural Sciences Research, 4, 59-70.

[30] Dinku, A. and Nedessa, B. (2012) Improvement of Grazing Lands through the Introduction of Improved Forage Species with Special Emphasis on Desho-Grass. MERET NEWs, No. 12. 